\title{
Workshop Fachinformation in Halle
}

Vom 27. bis 29. Juni 1994 fand an der Martin-Luther Universität Halle-Wittenberg der „5. Workshop Fachinformation" statt. Er beschäftigte sich mit dem Stand des derzeitig laufenden DMV-Projektes und den Perspektiven elektronischer Fachinformation in der Mathematik. Aus den dort gehaltenen Vorträgen sind die folgenden Beiträge auf den Seiten 19 bis 54 entstanden. Sie zeigen die brisante Situation von Publikationen und Bibliotheken und sollen helfen, die Diskussion darüber in Gang zu halten.

Die Redaktion würde sich über Meinungsäußerungen dazu freuen.

Ein ähnlicher Workshop fand in Dezember '94 in Berkeley statt.

\section{Tragic loss or good riddance? The impending demise of traditional scholarly journals}

\author{
von Andrew M. Odlyzko
}

Die hier vorliegende kurze Fassung des Artikel ist bereits in der Januar Ausgabe der „Notices of the AMS“ erschienen. Eine französische Übersetzung der kurzen Fassung von Dominique Foata wird in der „Gazette des mathématiciens" erscheinen. Die lange Version dieses Beitrags, die Datei tragic.loss.long.ps, ist per FTP von dem Rechner ftp.att.com aus dem Verzeichnis /pub/att/math.odlyzko zu bekommen.

\section{Introduction}

Traditional printed journals are a familiar and comfortable aspect of scholarly work. They have been the primary means of communicating research results, and as such have performed an invaluable service. However, they are an awkward artifact, although a highly developed one, of the print technology that was the only means available over the last few centuries for large-scale communication. The growth of the scholarly literature, together with the rapidly increasing power and availability of electronic technology, are creating tremendous pressures on journals. The purpose of this article is to give a broad picture of these pressures and their likely outcome, and to argue that the coming changes may be abrupt.

It is often thought that changes will be incremental, with perhaps a few electronic journals appearing and further use of email, ftp, etc. My guess is that change will be far more drastic. Traditional scholarly journals will likely disappear within 10 to 20 years. The electronic alternatives will be different from current periodicals, even though they may carry the same titles. There are obvious dangers in discontinuous change away from a system that has served the scholarly community well [Quinn]. However, I am convinced that future systems of communication will be much better than the traditional journals. $\mathrm{Al}-$ though the transition may be painful, there is the promise of a substantial increase in the effectiveness of scholarly work. Publications delays will disappear, and reliability of the literature will increase with opportunities to add comments to papers and attach references to later works that cite them. This promise of improved communication is especially likely to be realized if we are aware of the issues, and plan the evolution away from the present system as early as possible. In any event, we do not have much choice since drastic change is inevitable no matter what our preferences are.

Predictions and comments in this article apply to most scholarly disciplines. However, I will write primarily about mathematics, since I am most familiar with that field and the data that I have is clearest for it. Different areas have different needs and cultures and are likely to follow somewhat different paths in the evolution of their communications.

\section{Growth of literature}

The impending changes in scholarly publications are caused by the confluence of two trends. One is the growth in the size of the scholarly literature; the other is the growth of electronic technology.

The number of scientific papers published annually has been doubling every 10-15 years for the last two centuries [Price]. Similar growth has been occurring in mathematics alone. In 1870 there were only about 840 papers published in mathematics. Today, about 50,000 papers are published annually. The growth has not been even, and a more careful look at the statistics shows that from the end of World War 2 until 1990, the number of papers published has been doubling about every 10 years [MR]. Growth has stopped recently, but this is likely to be a temporary pause of the kind that have occurred before. 